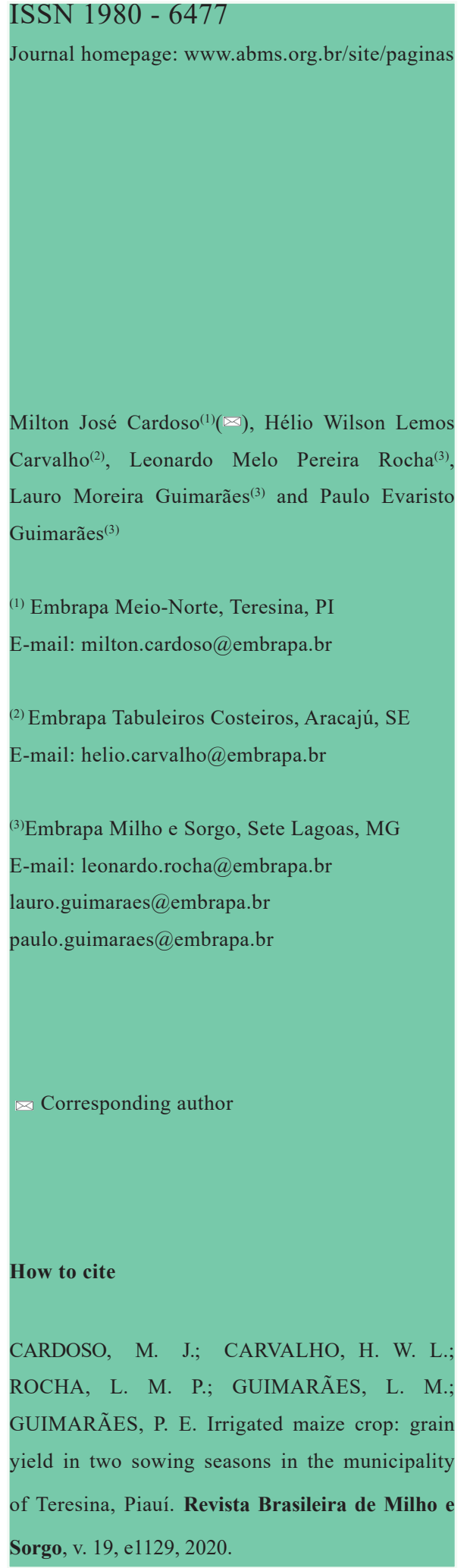

\section{IRRIGATED MAIZE CROP: GRAIN YIELD IN TWO SOWING SEASONS IN THE MUNICIPALITY OF TERESINA, PIAUÍ}

\begin{abstract}
The objective of this work was to evaluate commercial maize hybrids, under conventional sprinkler irrigation, in two sowing seasons (July and August 2017), in the municipality of Teresina, Piauí. A randomized block design was used, with two replications and 39 treatments (commercial maize hybrids). The characteristics evaluated were grain yield, water use efficiency, number of ears and number of grains per area. For the experiment with sowing done in July 2017, the average grain yield was $9.82 \mathrm{Mg} \mathrm{ha}^{-1}$ and the water use efficiency was $1.9 \mathrm{~kg} \mathrm{~m}^{-3}$, which are, respectively, $4.7 \%$ and $15.8 \%$ higher in relation to the experiment with sowing done in August 2017. Regardless of the sowing season, grain yields over $10.0 \mathrm{Mg}$ ha-1 of three hybrids (LG 6418, CD $3880 \mathrm{PW}$ and 2A $401 \mathrm{PW}$ ) stand out. The yield components, number of kernels per ear and grain mass per ear, show high values of correlation (over 0.80 ) with grain yield.
\end{abstract}

Keywords: Zea mays, water use efficiency, air temperature.

\section{MILHO IRRIGADO: PRODUTIVIDADE DE GRÃOS EM DUAS ÉPOCAS DE SEMEADURA NO MUNICÍPIO DE TERESINA, PIAUÍ}

Resumo - O presente trabalho teve como objetivo avaliar híbridos comerciais de milho, sob irrigação por aspersão convencional, em duas épocas de semeadura (julho e agosto de 2017) no município de Teresina, Piauí. Foi utilizado o delineamento experimental em blocos ao acaso, com duas repetições e 39 tratamentos (híbridos comerciais de milho). As características avaliadas foram produtividade de grãos, eficiência de uso da água, número de espigas e número de grãos por área. A produtividade de grãos média do ensaio com semeadura em julho/2017 foi de 9,82 $\mathrm{Mg} \mathrm{ha}^{-1}$, com eficiência de uso da água de $1,9 \mathrm{~kg} \mathrm{~m}^{-3}$, respectivamente, superior em $4,7 \%$ e 15,8 \% em relação a do ensaio com época de semeadura em agosto/2017. Independente da época de semeadura, produtividades de grãos acima de $10,0 \mathrm{Mg} \mathrm{ha}^{-1}$ de três híbridos (LG 6418, CD 3880 PW e 2 A 401 PW) se sobressaem. Os componentes de rendimentos, número de grãos por espiga e massa de grãos por espiga apresentam valores de correlação de alta magnitude (acima de 0,80 ) com a produtividade de grãos.

Palavras-chave: Zea mays, eficiência de uso da água, temperatura do ar. 
Maize crop yield is the result of the cultivar's genetic potential, soil and climate conditions in the cultivation area, as well as crop management. Under no water stress conditions, the factors that most influence maize yield are insolation and air temperature. The crop presents better development when the days are sunny, with higher daytime temperature and milder nighttime temperature (Bergamaschi \& Matzenauer, 2014; Sangoi et al., 2010).

Due to the weather variations that occur every year, yield and production present great interannual variability (Berlato et al., 2005). Therefore, the characterization of phenological changes that occur in the maize plant, at different sowing seasons, is important to define the adoption of cultivation practices, targeting the best use of environmental conditions and maximization of grain yield in each season.

Alves et al. (2011) observed that, under optimal conditions of water availability, that is, in irrigated cropping systems, the factors that most influence maize crop yield are the variations of air temperature and incident solar radiation. Since the maize plant highly benefits from solar radiation, it is very sensitive to the lack of light and, because of that, in cloudy days, there is a drop in the photosynthesis rate, which may reduce yield. Moreover, high daytime air temperature shortens the crop cycle, which, associated with high maintenance respiration rates as a result of high nighttime temperature, also reduces yield. That explains the considerable interannual variability in average maize yield, even under irrigated regime (Bergamaschi \& Matzenauer, 2014).

Irrigated systems are an alternative to mitigate water stress effects resulting from the irregular rainfall regime. However, due to water shortage periods and the competition for water use, it is necessary to employ management strategies that optimize the use of that resource. Even with no occurrence of water stress, due to the use of irrigation systems, and since incident solar radiation and air temperature affect maize yield, it is important to evaluate which is the most suitable season for cultivation, according to the differences in those climate variables.

In the present study, 39 maize hybrids were evaluated, under irrigation regime, in two sowing seasons, in the municipality of Teresina, Piauí.

\section{Material and Methods}

Two experiments, one with sowing done in July and the other with sowing done in August 2017, were conducted in the experimental area $\left(5^{\circ} 05^{\prime} \mathrm{S}, 42^{\circ} 29^{\prime} \mathrm{W}\right.$, and $72 \mathrm{~m}$ altitude - data obtained through GPS) of Embrapa Mid-North, in the municipality of Teresina, Piauí. It is located in the central-north mesoregion of Piauí state, in soil classified as dystrophic Fluvic Neosol, which presented low activity clay and low base saturation $(\mathrm{V}<50 \%$ ), both in most part of $\mathrm{C}$ horizon (Santos et al., 2018; Melo et al., 2014). The experiments were conducted under conventional sprinkler irrigation that was managed based on the crop evapotranspiration replacement, which was 
calculated from the reference evapotranspiration estimated with application of Penman-Monteith method and crop coefficients (Souza et al., 2015).

The soil water content was monitored up to the $0.70 \mathrm{~m}$ depth with the use of Diviner 2000. In both experiments, irrigation depths of $520 \mathrm{~mm}$ and $580 \mathrm{~mm}$ were applied in a 100-day cycle, with an average daily consumption of $5.2 \mathrm{~mm}$ and $5.8 \mathrm{~mm}$, respectively, in sowing carried out in July and August.

The results of soil fertility analyses, which were conducted in the Soil Fertility Laboratory of Embrapa Mid-North, indicated the following: $\mathrm{pH}$ in water $(1: 2.5)=6.1$; phosphorus $\left(\mathrm{mg} \mathrm{dm} \mathrm{dm}^{-3}\right)=22.1$; potassium $\left(\mathrm{mg} \mathrm{dm}^{-3}\right)=$ 119.3; calcium ( mmolc $\left.\mathrm{dm}^{-3}\right)=23.3$; and magnesium (mmolc $\left.\mathrm{dm}^{-3}\right)$ and O.M. $\left(\mathrm{g} \mathrm{kg}^{-1}\right)=$ 26.5. Fertilization was carried out by the time of sowing with 50,80 and $70 \mathrm{~kg}$ of $\mathrm{N}, \mathrm{P}_{2} \mathrm{O}_{5} \& \mathrm{~K}_{2} \mathrm{O}$ $\mathrm{ha}^{-1}$, respectively, and in topdressing with $100 \mathrm{~kg}$ of $\mathrm{N} \mathrm{ha} \mathrm{h}^{-1}$ by the time of the sixth fully emerged leaf, using the following fertilizers as sources: ammonium sulfate $(\mathrm{N})$, triple superphosphate $\left(\mathrm{P}_{2}\right.$ $\left.\mathrm{O}_{5}\right)$ and potassium chloride $\left(\mathrm{K}_{2} \mathrm{O}\right)$.

A randomized block design was used, with two replications and 39 treatments - maize hybrids (Table 1). Each plot consisted of four rows with $5.0 \mathrm{~m}$ length, spaced $0.70 \mathrm{~m}$ apart, with spacing of $0.20 \mathrm{~m}$ between holes within the rows, keeping one plant per hole after thinning. The two central rows $\left(7.0 \mathrm{~m}^{2}\right)$ were used as useful area. The number of days and average data for minimum and maximum air temperature and solar radiation (obtained from the agrometeorological station installed 350 meters away from the experimental area) were recorded for the period from sowing to tasseling $(50 \%$ of the plants with visible tassels), from tasseling to silking (50\% of the plants with visible style-stigma), and from silking to physiological maturity, when there is formation of the black layer in grains (Figures 1 $\& 2$ ). It was assumed that, as from the flowering stage, there is no longer stem and leaf growth, with emergence of kernels and their subsequent filling and loss of moisture.

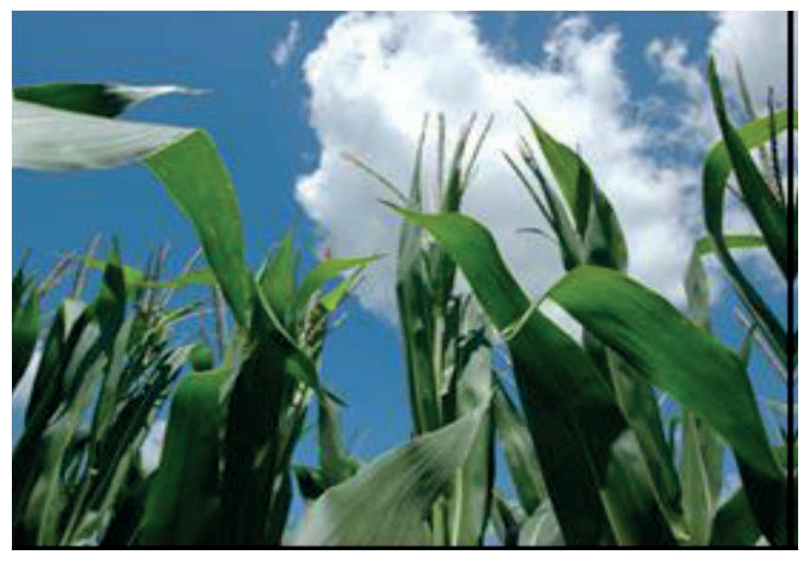

Figure 1. Maize plant in tasseling stage - Ritchie et al. (1993).

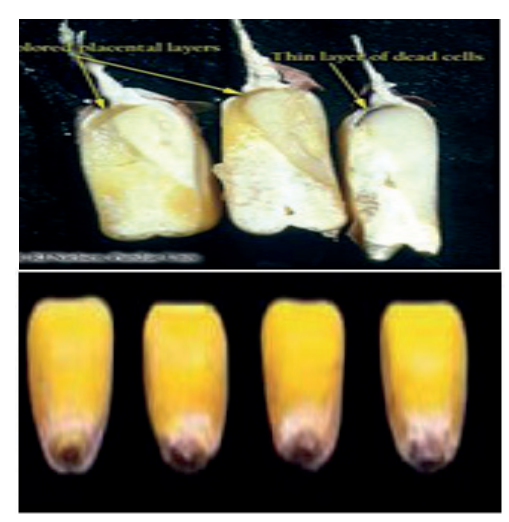

Figure 2. Maize plant in physiological maturity stage - Ritchie et al. (1993). 
Table 1. Characteristics of commercial hybrids used in the experiments. Teresina, PI 2017

\begin{tabular}{|c|c|c|c|c|}
\hline & Hybrid & Type & Grain Texture & Company \\
\hline 1 & 2B $433 \mathrm{PW}$ & $\mathrm{TH}$ & SMDENT & DOW AGROSCI SE E BI \\
\hline 2 & MG 580 PW & SH & SMFLINT & MORGAN SEMENTES \\
\hline 3 & RB 9004 PRO & $\mathrm{SH}$ & DENT & RIBER KWS SE S.A. \\
\hline 4 & 2 B 633 PW & $\mathrm{TH}$ & SMFLINT & DOW AGROSCI SE E BI \\
\hline 5 & IMPACTO VIP3 & $\mathrm{SH}$ & FLINT & SYNGENTA SEEDS LTDA \\
\hline 6 & LG 6053 PRO2 & - & - & LIMAGRAIN BRASIL S.A. \\
\hline 7 & 2B $512 \mathrm{PW}$ & $\mathrm{TH}$ & SMFLINT & DOW AGROSCI SE E BI \\
\hline 8 & FEROZ VIP & $\mathrm{DH}$ & FLINT & SYNGENTA SEEDS LTDA \\
\hline 9 & KWX 76610 & - & - & -- \\
\hline 10 & LG 6030 RR2 & $\mathrm{SH}$ & SMFLINT & LIMAGRAIN BRASIL S.A. \\
\hline 11 & 2 B 610 PW & $\mathrm{SH}$ & SMDENT & DOW AGROSC SE E BI \\
\hline 12 & XB 8010 & $\mathrm{DH}$ & SMDENT & SEMEALI SE HÍBRIDAS LTDA \\
\hline 13 & 2 B 587 PW & $\mathrm{SH}$ & SMDENT & DOW AGROSC SE E BI \\
\hline 14 & RB 9110 PRO & $\mathrm{SH}$ & SMDENT & RIBER KWS SE S.A. \\
\hline 15 & XB 6012 BT & $\mathrm{SH}$ & SMFLINT & SEMEALI SE HÍBRIDAS LTDA \\
\hline 16 & 90 XB 06 BT & $\mathrm{SH}$ & SMFLINT & SEMEALI SE HÍBRIDAS LTDA \\
\hline 17 & XB 8030 & $\mathrm{DH}$ & SMFLINT & SEMEALI SE HÍBRIDAS LTDA \\
\hline 18 & RB 9006 PRO & $\mathrm{SH}$ & SMFLINT & RIBER KWS SE S.A. \\
\hline 19 & RB 9005 PRO & $\mathrm{SH}$ & SMDENT & RIBER KWS SE S.A. \\
\hline 20 & 2 B 810 PW & SH & SMFLINT & DOW AGROSCI SE E BI \\
\hline 21 & XB 8018 & $\mathrm{DH}$ & SMFLINT & SEMEALI SE HÍBRIDAS LTDA \\
\hline 22 & MG 600 PW & $\mathrm{SH}$ & SMFLINT & MORGAN SEMENTES \\
\hline 23 & 30 A 91 PW & $\mathrm{SHm}$ & SMFLINT & DOW AGROSCI SE E BI \\
\hline 24 & 13 B 275 PW & SH & SMDENT & DEKALB \\
\hline 25 & RB 9077 PRO & $\mathrm{TH}$ & FLINT & RIBER KWS SE S.A. \\
\hline 26 & LG 6030 PRO2 & $\mathrm{SH}$ & SMFLINT & LIMAGRAIN BRASIL S.A. \\
\hline 27 & RB 9210 PRO & $\mathrm{SH}$ & FLINT & RIBER KWS SE S.A. \\
\hline 28 & MG 652 PW & $\mathrm{SHm}$ & SMFLINT & MORGAN SEMENTES \\
\hline 29 & LG 6418 & $\mathrm{TH}$ & FLINT & LIMAGRAIN BRASIL S.A. \\
\hline 30 & 60 XB 14 & $\mathrm{SH}$ & FLINT & SEMEALI SE HÍBRIDAS LTDA \\
\hline 31 & 20 A 78 PRO & $\mathrm{TH}$ & SMDENT & MORGAN SEMENTES \\
\hline 32 & 30 A 37 PW & $\mathrm{SH}$ & SMFLINT & MORGAN SEMENTES \\
\hline 33 & CD $3770 \mathrm{PW}$ & $\mathrm{SHm}$ & SMFLINT & COODETEC \\
\hline 34 & CR 804 & - & - & - \\
\hline 35 & LG 6310 & $\mathrm{TH}$ & SMFLINT & LIMAGRAIN BRASIL S.A. \\
\hline 36 & CD 3880 PW & - & - & COODETEC \\
\hline 37 & $2 \mathrm{~A} 401 \mathrm{PW}$ & $\mathrm{SH}$ & SMFLINT & DOW AGROSCI SE E BI \\
\hline 38 & RB 9308 PRO & $\mathrm{TH}$ & FLINT & RIBER KWS SE S.A. \\
\hline 39 & CD 3612 PW & $\mathrm{TH}$ & SMDENT & COODETEC \\
\hline
\end{tabular}

- No information. SMFLINT: Semi-flint and SMDENT: Semi-dent. 
The characteristics assessed were grain yield (GY in $\mathrm{Mg} \mathrm{ha}^{-1}$ ) with $14 \%$ of moisture; number of ears (NE) and number of grains (NG) per area; hundred-grain weight (HGW); grain index (GI) and ear index (EI); grain mass per ear (GME); and water use efficiency (WUE). The WUE was calculated from the ratio between the GY obtained (weight $\mathrm{ha}^{-1}$ ) and water volume consumed $\left(\mathrm{m}^{3}\right.$ $\left.\mathrm{ha}^{-1}\right)$. The WUE is expressed in kilogram of maize grains per cubic meter of water used.

For the study of correlation with grain yield, the following were also evaluated: plant height and ear height $(\mathrm{cm})$, hundred-grain weight $(\mathrm{g})$, grain index, ear index and grain mass per ear. Data were submitted to analysis of variance and the means for grain yield and water use efficiency were compared by Scott-Knott test at 5\% significance (Zimmerman, 2014).

\section{Results and Discussion}

The analysis of variance showed effect $(\mathrm{P}<0.01)$ of the hybrid $\mathrm{x}$ sowing season interaction on the following characteristics: plant and ear heights, grain mass per ear, number of kernels per ear, grain yield and water use efficiency. That shows that the hybrids present different behavior depending on the sowing season (Table 2).

Higher grain yields and water use efficiency were observed in the sowing done in July 2017, with the average values for that experiment being $9.84 \mathrm{Mg} \mathrm{ha}^{-1}$ and $1.9 \mathrm{~kg} \mathrm{~m}^{-3}$, respectively, which are $4.91 \%$ and $18.8 \%$ higher when compared with the sowing done in August 2017. In the July sowing season, seventeen hybrids presented production above the experiment average (9.84 $\mathrm{Mg} \mathrm{ha}^{-1}$ ) and made better use of the water in the grain production (equivalent or superior to 2.1 $\mathrm{kg} \mathrm{m}^{-3}$ ), especially the hybrids 2 B 512 PW, 2 B 587 PW, CD 3880 PW, LG 6418, and MG 652 $\mathrm{PW}$, with grain mass over $11.0 \mathrm{Mg} \mathrm{ha}^{-1}$ (Tables $3 \& 4)$. In the August sowing season, with the general experiment average of $9.38 \mathrm{Mg} \mathrm{ha}^{-1}$, the hybrids LG 6418, CD 3880 PW, CD 3612 PW, and RB 9005 PRO stood out, with grain yields over $11 \mathrm{Mg} \mathrm{ha}^{-1}$ and water use efficiency equivalent or superior to $1.9 \mathrm{~kg} \mathrm{~m}^{-3}$.

Despite the significance of the hybrid $\mathrm{x}$ sowing season interaction for grain yield, it was possible to find hybrids with grain yield above the mean verified for the sowing seasons. The grain yield is graphically represented in Figure 3, where the $\mathrm{x}$-axis shows the average grain yield when the sowing was done in July, and the $y$-axis shows the grain yield obtained in the sowing done in August. The Figure is divided into four quadrants, according to the methodology proposed and adapted by Fageria \& Baligar (1993). The hybrids with grain yield above the mean of the experiment planted in August are in the upper left quadrant, while the hybrids with grain yield below the mean are in the lower left quadrant. In both quadrants, the hybrids show grain yield inferior to the mean in relation to the sowing done in July. The hybrids positioned in the upper and lower right quadrants attained higher grain yield in relation to the general mean of the experiment 
Table 2. Mean square values for the following characteristics: plant height (PH), ear height (EH), hundred-grain weight (HGW), grain index (GI), ear index (EI), grain mass per ear (GME), number of kernels per ear (NKE), grain yield per hectare (GY), and water use efficiency (WUE) of 39 maize hybrids, under irrigation regime, in two sowing seasons. Teresina, Piaú 2017

\begin{tabular}{|c|c|c|c|c|c|c|c|c|c|}
\hline \multirow[t]{2}{*}{ S.V. } & \multicolumn{9}{|c|}{ Mean squares } \\
\hline & $\mathrm{PH}$ & EH & HGW & GI & EI & GME & NKE & GY & WUE \\
\hline $\mathrm{Se}$ & $19833.9 * *$ & $1869.3 * *$ & $41.03 * *$ & 0.0000448 & 0.000984 & $3278.9^{* *}$ & $6.487 * *$ & $8251733 * *$ & $2.949 * *$ \\
\hline Hyb & $742.0 * *$ & $366.1 * *$ & 2.07 & 0.00142 & $0.00177 *$ & $410.2 * *$ & $2.527 * *$ & $3060706 * *$ & $0.099 * *$ \\
\hline $\mathrm{B} 1$ & $457.4 * *$ & $246.7 * *$ & $12.09 * *$ & $0.00742 * *$ & 0.000749 & $474.8 * *$ & $4.885^{* *}$ & $4065861 * *$ & $0.123 * *$ \\
\hline Se $\mathrm{x}$ hyb & $475.9 * *$ & $291.5^{* *}$ & 2.26 & 0.00123 & 0.00127 & $262.6^{* *}$ & $1.702 * *$ & $1325026^{* *}$ & $0.042 * *$ \\
\hline Residue & 30.5 & 46.5 & 2.44 & 0.00111 & 0.000914 & 90.1 & 0.7705 & 447331 & 0.0139 \\
\hline $\mathrm{CV}(\%)$ & 2.84 & 7.03 & 4.43 & 3.93 & 2.90 & 6.91 & 4.45 & 6.96 & 6.73 \\
\hline
\end{tabular}

$\mathrm{Se}=$ sowing seasons; $\mathrm{Hyb}=$ hybrids; $* *(\mathrm{P}<0.01)$ and $*(\mathrm{P}<0.05)$ as per $\mathrm{F}$-test.

Table 3. Mean values for grain yield of 39 commercial maize hybrids, in two sowing seasons, under irrigation regime. Teresina, PI 2017

\begin{tabular}{cccccc}
\hline & Hybrids & \multicolumn{2}{c}{ Grain yield $\left(\mathrm{Mg} \mathrm{ha}^{-1}\right)$} \\
\cline { 3 - 5 } & & \multicolumn{2}{c}{ Sowing in July } & \multicolumn{2}{c}{ Sowing in August } \\
\hline 1 & 2 B 433 PW & 10.21 & $\mathrm{~b}$ & 9.37 & $\mathrm{a}$ \\
3 & MG 580 PW & 8.49 & $\mathrm{~d}$ & 9.23 & $\mathrm{a}$ \\
4 & RB 9004 PRO & 9.60 & $\mathrm{c}$ & 9.24 & $\mathrm{a}$ \\
5 & 2 B 633 PW & 9.51 & $\mathrm{c}$ & 9.67 & $\mathrm{a}$ \\
6 & IMPACTO VIP3 & 9.55 & $\mathrm{c}$ & 8.17 & $\mathrm{~b}$ \\
7 & LG 6053 PRO2 & 9.62 & $\mathrm{c}$ & 8.69 & $\mathrm{~b}$ \\
8 & 2 B 512 PW & 11.05 & $\mathrm{a}$ & 8.49 & $\mathrm{~b}$ \\
9 & FEROZ VIP & 9.23 & $\mathrm{c}$ & 7.76 & $\mathrm{~b}$ \\
10 & KWX 76610 & 9.81 & $\mathrm{c}$ & 8.99 & $\mathrm{a}$ \\
11 & LG 6030 RR2 & 9.29 & $\mathrm{c}$ & 9.53 & $\mathrm{a}$ \\
12 & 2 B 610 PW & 10.52 & $\mathrm{~b}$ & 9.24 & $\mathrm{a}$ \\
13 & XB 8010 & 7.61 & $\mathrm{~d}$ & 7.63 & $\mathrm{~b}$ \\
14 & 2B 587 PW & 11.47 & $\mathrm{a}$ & 9.13 & $\mathrm{a}$ \\
15 & RB 9110 PRO & 10.02 & $\mathrm{c}$ & 9.87 & $\mathrm{a}$ \\
16 & XB 6012 BT & 9.33 & $\mathrm{c}$ & 10.59 & $\mathrm{a}$ \\
17 & 90 XB 06 BT & 9.69 & $\mathrm{c}$ & 10.11 & $\mathrm{~b}$ \\
18 & XB 8030 & 7.68 & $\mathrm{~d}$ & $\mathrm{c}$ & $\mathrm{b}$ \\
19 & RB 9006 PRO & 10.04 & $\mathrm{c}$ & 6.39 & $\mathrm{a}$ \\
20 & RB 9005 PRO & 9.73 & $\mathrm{c}$ & 11.02 & $\mathrm{a}$ \\
21 & 2B 810 PW & 9.80 & C & 9.83 & $\mathrm{a}$
\end{tabular}


Table 3 (continuation). Mean values for grain yield of 39 commercial maize hybrids, in two sowing seasons, under irrigation regime. Teresina, PI 2017

\begin{tabular}{lccccc}
22 & MG 600 PW & 10.39 & b & 9.37 & a \\
23 & 30 A 91 PW & 10.24 & b & 9.69 & a \\
24 & 13 B 275 PW & 9.65 & c & 10.16 & a \\
25 & RB 9077 PRO & 9.35 & c & 7.70 & b \\
26 & LG 6030 PRO2 & 9.58 & c & 10.35 & $\mathrm{a}$ \\
27 & RB 9210 PRO & 9.62 & $\mathrm{c}$ & 9.23 & $\mathrm{a}$ \\
28 & MG 652 PW & 11.23 & $\mathrm{a}$ & 9.96 & $\mathrm{a}$ \\
29 & LG 6418 & 11.37 & $\mathrm{a}$ & 11.564 & $\mathrm{a}$ \\
30 & 60 XB 14 & 9.98 & $\mathrm{c}$ & 9.00 & $\mathrm{a}$ \\
31 & 20 A 78 PRO & 9.48 & $\mathrm{c}$ & 8.91 & $\mathrm{a}$ \\
32 & 30 A 37 PW & 10.75 & $\mathrm{~b}$ & 9.68 & $\mathrm{a}$ \\
33 & CD 3770 PW & 9.87 & $\mathrm{c}$ & 10.00 & $\mathrm{a}$ \\
34 & CR 804 & 10.16 & $\mathrm{~b}$ & 9.71 & $\mathrm{a}$ \\
35 & LG 6310 & 9.35 & $\mathrm{c}$ & 6.97 & $\mathrm{a}$ \\
36 & CD 3880 PW & 11.05 & $\mathrm{a}$ & 11.66 & $\mathrm{a}$ \\
37 & 2 A 401 PW & 10.58 & $\mathrm{~b}$ & 10.98 & $\mathrm{a}$ \\
38 & RB 9308 PRO & 9.35 & $\mathrm{c}$ & 10.35 & $\mathrm{a}$ \\
39 & CD 3612 PW & 9.42 & $\mathrm{c}$ & 11.26 & \\
\hline
\end{tabular}

Note: average grain yield for sowing in July $\left(9.84 \mathrm{Mg} \mathrm{ha}^{-1}\right)$ and sowing in August $\left(9.38 \mathrm{Mg} \mathrm{ha}^{-1}\right)$. General mean value for grain yield (two seasons): $9.61 \mathrm{Mg} \mathrm{ha}^{-1}$. Means with the same letter in the column are identical at $5 \%$ significance level as per Scott-Knott test.

Table 4. Mean values for water use efficiency of 39 commercial maize hybrids, in two sowing seasons, under irrigation regime. Teresina, PI 2017

\begin{tabular}{|c|c|c|c|c|c|}
\hline & \multirow[t]{2}{*}{ Hybrids } & \multicolumn{4}{|c|}{ Water use efficiency $\left(\mathrm{kg} \mathrm{m}^{-3}\right)$} \\
\hline & & \multicolumn{2}{|c|}{ Sowing in July } & \multicolumn{2}{|c|}{ Sowing in August } \\
\hline 1 & 2B $433 \mathrm{PW}$ & 2.0 & $\mathrm{~b}$ & 1.6 & $\mathrm{a}$ \\
\hline 2 & MG 580 PW & 1.6 & $\mathrm{~d}$ & 1.6 & $\mathrm{a}$ \\
\hline 3 & RB 9004 PRO & 1.8 & $\mathrm{c}$ & 1.6 & $\mathrm{a}$ \\
\hline 4 & 2B $633 \mathrm{PW}$ & 1.8 & $\mathrm{c}$ & 1.7 & $\mathrm{a}$ \\
\hline 5 & IMPACTO VIP3 & 1.8 & $\mathrm{c}$ & 1.4 & $\mathrm{~b}$ \\
\hline 6 & LG 6053 PRO2 & 1.8 & $\mathrm{c}$ & 1.5 & $\mathrm{~b}$ \\
\hline 7 & 2B $512 \mathrm{PW}$ & 2.1 & $\mathrm{a}$ & 1.5 & $\mathrm{~b}$ \\
\hline 8 & FEROZ VIP & 1.8 & $\mathrm{c}$ & 1.3 & $\mathrm{~b}$ \\
\hline 9 & KWX 76610 & 1.9 & $\mathrm{c}$ & 1.6 & a \\
\hline 10 & LG 6030 RR2 & 1.8 & $\mathrm{c}$ & 1.6 & $\mathrm{a}$ \\
\hline 11 & 2B 610 PW & 2.0 & $\mathrm{~b}$ & 1.6 & $\mathrm{a}$ \\
\hline
\end{tabular}


Table 4 (continuation). Mean values for water use efficiency of 39 commercial maize hybrids, in two sowing seasons, under irrigation regime. Teresina, PI 2017.

\begin{tabular}{|c|c|c|c|c|c|}
\hline 12 & XB 8010 & 1.5 & $\mathrm{~d}$ & 1.3 & $\mathrm{~b}$ \\
\hline 13 & 2B $587 \mathrm{PW}$ & 2.2 & $\mathrm{a}$ & 1.6 & $\mathrm{a}$ \\
\hline 14 & RB 9110 PRO & 1.9 & $\mathrm{c}$ & 1.7 & $\mathrm{a}$ \\
\hline 15 & XB 6012 BT & 1.8 & $\mathrm{c}$ & 1.8 & $\mathrm{a}$ \\
\hline 16 & 90 XB 06 BT & 1.9 & $\mathrm{c}$ & 1.7 & $\mathrm{a}$ \\
\hline 17 & XB 8030 & 1.5 & $\mathrm{~d}$ & 1.2 & $\mathrm{~b}$ \\
\hline 18 & RB 9006 PRO & 1.9 & $\mathrm{c}$ & 1.1 & $\mathrm{~b}$ \\
\hline 19 & RB 9005 PRO & 1.9 & $\mathrm{c}$ & 1.9 & $\mathrm{a}$ \\
\hline 20 & 2B $810 \mathrm{PW}$ & 1.9 & $\mathrm{c}$ & 1.7 & $\mathrm{a}$ \\
\hline 21 & XB 8018 & 1.9 & $\mathrm{c}$ & 1.6 & $\mathrm{a}$ \\
\hline 22 & MG 600 PW & 2.0 & $\mathrm{~b}$ & 1.6 & $\mathrm{a}$ \\
\hline 23 & 30 A 91 PW & 2.0 & $\mathrm{~b}$ & 1.7 & $\mathrm{a}$ \\
\hline 24 & 13 B 275 PW & 1.9 & $\mathrm{c}$ & 1.8 & $\mathrm{a}$ \\
\hline 25 & RB 9077 PRO & 1.8 & $\mathrm{c}$ & 1.3 & $\mathrm{~b}$ \\
\hline 26 & LG 6030 PRO2 & 1.8 & $\mathrm{c}$ & 1.8 & $\mathrm{a}$ \\
\hline 27 & RB 9210 PRO & 1.9 & $\mathrm{c}$ & 1.6 & $\mathrm{a}$ \\
\hline 28 & MG 652 PW & 2.2 & $\mathrm{a}$ & 1.7 & $\mathrm{a}$ \\
\hline 29 & LG 6418 & 2.2 & $\mathrm{a}$ & 2.0 & $\mathrm{a}$ \\
\hline 30 & 60 XB 14 & 1.9 & $\mathrm{c}$ & 1.6 & $\mathrm{a}$ \\
\hline 31 & 20 A 78 PRO & 1.8 & $\mathrm{c}$ & 1.5 & $\mathrm{a}$ \\
\hline 32 & 30 A 37 PW & 2.1 & $\mathrm{~b}$ & 1.7 & $\mathrm{a}$ \\
\hline 33 & CD 3770 PW & 1.9 & $\mathrm{c}$ & 1.7 & $\mathrm{a}$ \\
\hline 34 & CR 804 & 2.0 & $\mathrm{~b}$ & 1.7 & $\mathrm{a}$ \\
\hline 35 & LG 6310 & 1.8 & $\mathrm{c}$ & 1.2 & $\mathrm{~b}$ \\
\hline 36 & CD 3880 PW & 2.1 & $\mathrm{a}$ & 2.0 & $\mathrm{a}$ \\
\hline 37 & 2 A 401 PW & 2.0 & $\mathrm{~b}$ & 1.9 & $\mathrm{a}$ \\
\hline 38 & RB 9308 PRO & 1.8 & $\mathrm{c}$ & 1.8 & $\mathrm{a}$ \\
\hline 39 & CD 3612 PW & 1.8 & $\mathrm{c}$ & 1.9 & $\mathrm{a}$ \\
\hline
\end{tabular}

Note: General mean of water use efficiency for sowing in July $\left(1.9 \mathrm{~kg} \mathrm{~m}^{-3}\right)$ and sowing in August $\left(1.6 \mathrm{~kg} \mathrm{~m}^{-3}\right)$. Means with the same letter in the column are identical at $\%$ significance level as per Scott-Knott test.

planted in July. The hybrids located in the upper right quadrant obtained the best results since they reached grain yields above the means for sowing carried out either in July or August.

The sowing season produces changes in the crop cycle and modifies physical and morphological aspects that may affect plant and ear heights, as well as yield components. Number of kernels per ear and grain mass per ear are variables that presented greater values in the July season in relation to the August season, being regarded as the main factors to differentiate the 


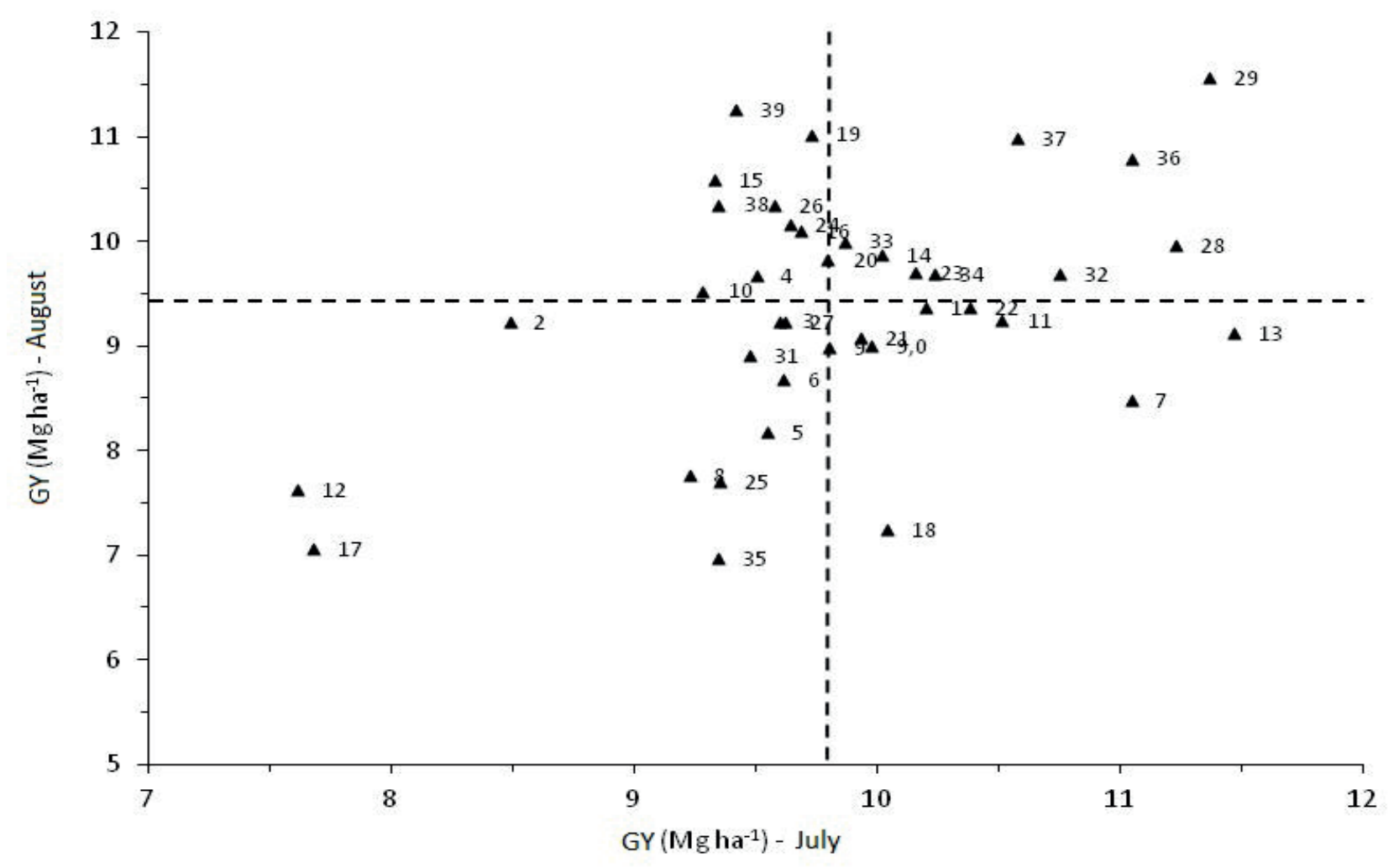

Figure 3. Scatter plot for grain yield of 39 commercial maize hybrids, cultivated under irrigation regime, and evaluated in two sowing seasons: July 2017 (x-axis) and August 2017 (y-axis). The hybrids corresponding to the numbers are listed in Table 3. Teresina, PI 2017

behavior of hybrids in the two seasons (Table 5). This fact is also demonstrated by the correlation between those components and the grain yield per hectare, which presented high values (Table 6) (Nogueira et al., 2012).

The periods (number of days) from sowing to tasseling and from silking to physiological maturity were longer, and the period from tasseling to silking was shorter, when the sowing season occurred in July (Table 7). In those periods, the average climate data relative to air temperature and solar radiation were higher in relation to the sowing season in August (Table 8), certainly favoring the hybrids, which could better express their yield potential. This fact can be demonstrated by the production of 7.67 bags of $60 \mathrm{~kg}(4.68 \%)$ more in relation to the August season (Alves et al., 2011; Sangoi et al., 2010). In irrigated crop systems, the factors that most influence the maize grain yield are the variations of air temperature and incident solar radiation. As it is a plant that highly benefits from solar radiation, it is very sensitive to the lack of light and, therefore, in cloudy days, there is a drop 
Table 5. Average data for the following characteristics: plant height $(\mathrm{PH}-\mathrm{cm})$, ear height $(\mathrm{EH}-\mathrm{cm})$, hundredgrain weight (HGW - g), grain index (GI), ear index (EI), grain mass per ear (GME - g), number of kernels per ear (NKE), grain yield per hectare (GY - $\mathrm{Mg} \mathrm{ha}^{-1}$ ), and water use efficiency (WUE - $\mathrm{kg} \mathrm{m}^{-3}$ ) of 39 commercial maize hybrids, in two sowing seasons, under irrigation regime. Teresina, PI 2017

\begin{tabular}{cccccccccc}
\hline SE & PH & EH & HGW & GI & EI & GME & NKE & GY & WUE \\
\hline JULY & $206 \mathrm{a}$ & $100 \mathrm{a}$ & $36 \mathrm{a}$ & $0.85 \mathrm{a}$ & $1.04 \mathrm{a}$ & $142 \mathrm{a}$ & $398 \mathrm{a}$ & $9.84 \mathrm{a}$ & $1.9 \mathrm{a}$ \\
& & & & & & & & & \\
AUGUST & $183 \mathrm{~b}$ & $94 \mathrm{a}$ & $35 \mathrm{a}$ & $0.85 \mathrm{a}$ & $1.04 \mathrm{a}$ & $133 \mathrm{~b}$ & $383 \mathrm{~b}$ & $9.38 \mathrm{a}$ & $1.6 \mathrm{a}$ \\
\hline
\end{tabular}

Means with the same letter in the column are identical at 5\% significance as per F-test.

Table 6. Pearson's correlation for grain yield, plant height $(\mathrm{PH})$, ear height $(\mathrm{EH})$, hundred-grain weight (HGW), grain index (GI), ear index (EI), grain mass per ear (GME), number of kernels per ear (NKE), and water use efficiency (WUE) of 39 commercial maize hybrids, in two sowing seasons, under irrigation regime. Teresina, PI 2017

\begin{tabular}{ccc}
\hline & Sowing season: July 2017 & Sowing season: August 2017 \\
PC & Grain yield & Grain yield \\
\hline PH & 0.07752 & $0.18389^{*}$ \\
EH & 0.08235 & $0.16669^{*}$ \\
HGW & -0.01028 & 0.00132 \\
GI & $0.59970^{* *}$ & $0.49363^{* *}$ \\
EI & $0.38278^{* *}$ & $0.37316^{* *}$ \\
GME & $0.91331^{* *}$ & $0.90094^{* *}$ \\
NKE & $0.86507^{* *}$ & $0.83295^{* *}$ \\
WUE & $0.99978^{* *}$ & $0.92332^{* *}$ \\
\hline
\end{tabular}

** and * significant at $1 \%$ and $5 \%$ significance level, respectively, as per t-test.

in the photosynthesis rate, which may reduce Conclusions yield. Moreover, high daytime air temperature shortens the crop cycle, which, associated with high maintenance respiration rates as a result of high nighttime temperature, also reduces yield. That is why there is a considerable interannual variability in average maize grain yield, even under irrigated regime (Alves et al., 2011).

Three hybrids (LG 6418, CD 3880 PW, and 2 A 401 PW) stand out when they are sown in July and August.

In the sowing carried out in July, the hybrids produce, on average, 7.67 bags of $60 \mathrm{~kg}$ more per hectare in relation to the sowing in August. 
Table 7. Average duration (in days) of the periods: from sowing (SO) to tasseling (TA), from tasseling to silking (SI), and from silking to physiological maturity (PM), of 39 maize hybrids, in two sowing seasons, under irrigation regime. Teresina, PI 2017

\begin{tabular}{c|c|c|c}
\hline \multicolumn{4}{c}{ Phenological Stages } \\
\hline Seasons & SO-TA & TA-SI & SI-PM \\
\hline July & 53 & 3 & 64 \\
August & 49 & 5 & 57 \\
\hline
\end{tabular}

Table 8. Average data of maximum and minimum air temperature $\left({ }^{\circ} \mathrm{C}\right)$ and solar radiation $\left(\mathrm{MJ} \mathrm{m}^{-2}\right)$, for the periods (days): from sowing (SO) to tasseling (TA), from tasseling to silking (SI), and from silking to physiological maturity (PM), of 39 commercial maize hybrids, in two sowing seasons, under irrigation regime. Teresina, PI 2017

\begin{tabular}{c|c|c|c|c|c|c|c|c|c}
\hline Seasons & \multicolumn{3}{|c}{ SO - TA } & \multicolumn{4}{c}{ TA - SI } & \multicolumn{3}{c}{ SI - PM } \\
\hline & Max & Min & Rd & Max & Min & Rd & Max & Min & Rd \\
\hline July & 34.9 & 21.1 & 17.2 & 36.6 & 22.2 & 19.4 & 37.4 & 23.1 & 18.5 \\
& & & & & & & & & \\
August & 36.8 & 21.8 & 18.7 & 37.7 & 22.8 & 18.7 & 36.7 & 24.3 & 17.4 \\
\hline
\end{tabular}

The number of kernels per ear and grain mass per ear are the yield components most correlated with grain yield.

\section{References}

ALVES, M. E. B.; ANDRADE, C. L. T.; RUIZCÁRDENAS, R.; AMARAL, T. A.; SILVA, D. F. Identificação e quantificação do efeito de fatores ambientais na produtividade da cultura do milho na região de Janaúba, MG. Revista Brasileira de Agricultura Irrigada, Fortaleza, v. 5, n. 3, p. 188-201, 2011. DOI: 10.7127/rbai.v5n300057.

BERGAMASCHI, H.; MATZENAUER, R. Proceedings. Lincoln: University of Nebraska,
O milho e o clima. Porto Alegre:Emater/RS Ascar, 2014. 84 p.

BERLATOA.M.;FARENZENA,H.;FONTANA, C.D. Associação entre El Niño Oscilação Sul e a produtividade do milho no Estado do Rio Grande do Sul. Pesquisa Agropecuária Brasileira, v.40, n.5, p.423-432, 2005. DOI: 10.1590/S0100$204 X 2005000500001$.

FAGERIA, N.K.; BALIGAR, V.C. Screening crop genotypes for mineral stresses. In: WORKSHOP ON ADAPTATION OF PLANTS TO SOIL STRESSES, 1993, Lincoln. DOI: https://doi.org/10.18512/rbms2020v19e1129 
1993. p.142-159. (Intsormil Publication, 94-2).

MELO, F. de B.; ANDRADE JÚNIOR, A.S; PESSOA, B.L. de O. Levantamento, zoneamento e mapeamento pedológico detalhado da área experimental da Embrapa Meio-Norte em Teresina, PI. Teresina:Embrapa Meio-Norte, 2014. 47 p. (Embrapa Meio-Norte. Documentos, 231).

NOGUEIRA, A.P.O.; SEDIYAMA, T.; SOUSA, L.B.; HAMAWAKI, O.T.; CRUZ, C.D.; PEREIRA, D.G.; MATSUO, E. Análise de trilha e correlações entre caracteres em soja cultivada em duas épocas de semeadura. Biosciense Journal, Uberlândia, v. 28, n. 6, p. $877-888,2012$

RITCHIE, S. W.; HANWAY, J. J.; BENSON, G. O. How a corn plant develops. Special Bulletin, Iowa, n. 48.1993. 20 p.
SANGOI, L.; SILVA, P.R.F.; ARGENTA, G.; RAMBO. L. Ecofisiologia da cultura do milho para altos rendimentos. Lages: Graphel; 2010.

SANTOS, H. G. dos; JACOMINE, P. K. T.; ANJOS, L. H. C. dos; OLIVEIRA, V. A. de; LUMBRERAS, J. F.; COELHO, M. R.; ALMEIDA, J. A. de; ARAÚJO FILHO, J. COELHO de; OLIVEIRA, J. B. de; CUNHA, T. J. F. Sistema brasileiro de classificação de solos. 5. ed. Rev. e Ampl. Brasília, DF: Embrapa, 2018. 356 p.

SOUZA, L.S. B..; MOURA, M.S.B. de; SEDYAMA, G.C.; SILVA, T.G.F. Requerimento hídrico e coeficiente de cultura do milho e feijãocaupi em sistemas exclusivo e consorciado. Revista Caatinga, Mossoró, v. 28, n. 4, p. 151 $-160,2015$

ZIMMERMANN, F.J.P. Estatística aplicada à pesquisa agrícola. 2 ed. Brasília, D.F.: Embrapa, 2014, 582 p. 